Brit. Heart J., 1963, 25, 560.

\title{
ELECTROCARDIOGRAPHIC OBSERVATIONS DURING AND AFTER ANOXIC ARREST FOR OPEN-HEART SURGERY*
}

\author{
BY
RHAGAVAN AMARASINGHAM, ARMAND A. LEFEMINE, EDUARDO SALAZAR, AND HAROLD D. LEVINE \\ From the Department of Surgery and Medical Clinic, Peter Bent Brigham Hospital, and Departments of Surgery and \\ Medicine, Harvard Medical School, Boston, Massachusetts, U.S.A.
}

Received September 28, 1962

Extensive laboratory and clinical investigations have been conducted on the electrocardiographic changes induced by interruption of the circulation to localized regions of the heart, but very little is known about ischæmia of the heart as a whole. Undoubtedly this is due to interest in the clinical state of myocardial infarction which, by and large, is the result of a localized disturbance in circulation. There is no corresponding entity of sustained total ischæmia of the heart. Open-heart operations using extracorporeal circulation and the induction of cardioplegia by the simple process of cross-clamping of the ascending aorta deprives the heart of its entire blood supply during the period of occlusion. Although this method of anoxic arrest at normothermic levels is now obsolete and has long been replaced by the technique of coronary perfusion with local hypothermia, the material gathered during the period in which this early technique was employed provides a unique body of material for the study of total anoxia of the heart. These observations are presented for their electrocardiographic and theoretical interest.

\section{SubJeCtS AND Methods}

This communication describes the electrocardiographic effects observed during and following aortic occlusion in 21 adult patients, aged 24 to 52 years. Of these patients 19 were subjected to open-heart surgery for the correction of advanced mitral or aortic valve disease, and two on account of congenital heart disease involving septal defects (Table). Fifteen of the patients were in advanced congestive heart failure and six were severely incapacitated by their disease.

All patients were digitalized before operation. Eighteen of the operations were performed at normal body temperature. The remaining three, carried out at temperatures varying from $27^{\circ} \mathrm{C}$. to $32^{\circ} \mathrm{C}$., are included, since their course did not differ significantly from those done at normal temperature. Intermittent low flow coronary perfusion was carried out in two patients. The duration of interrupted coronary flow varied from 18 to 54 minutes.

The heart was approached through a right antero-lateral thoracotomy with transsection of the sternum. The superior and inferior venæ cavæ were cannulated through the right atrial appendage for gravity drainage of the venous return to the heart. A femoral artery was exposed and cannulated for arterial return. Oxygenation and flow were provided by a Kay-Cross oxygenator and DeBakey pump. The patient was first stabilized on partial bypass by diverting a portion of the venous return to the pump-oxygenator. Total bypass was produced by tightening tapes previously placed around the venæ cavæ at their junctions with the right atrium. The aorta was then cross-clamped and the heart was arrested by anoxia.

The aortic valve was approached directly through the wall of the aorta. The mitral valve was exposed

* Supported by USPHS grants No. H2419, HTS5231 and HTS5234 (C2).

This material was presented in large part at Fourth World Congress of Cardiology in Mexico City. 
TABLE

Clinical and Operative Data in 21 Patients Subjected to Anoxic Cardiac Arrest by Aortic Clamping

\begin{tabular}{|c|c|c|c|c|c|c|c|c|}
\hline Patient & $\begin{array}{l}\text { Age } \\
\text { and } \\
\text { sex }\end{array}$ & Diagnosis & $\begin{array}{l}\text { Clinical } \\
\text { status }\end{array}$ & Operations & $\begin{array}{l}\text { Duration } \\
\text { of aortic } \\
\text { occlusion } \\
\text { (min.) }\end{array}$ & $\begin{array}{l}\text { Duration } \\
\text { of assisted } \\
\text { circulation } \\
\text { after arrest } \\
\text { (min.) }\end{array}$ & Result & Cause of death \\
\hline A.F. & $\begin{array}{l}26 \\
\mathbf{M}\end{array}$ & $\begin{array}{l}\text { Tetralogy } \\
\text { of Fallot }\end{array}$ & IV & $\begin{array}{l}\text { Closure I.V.S.D. } \\
\text { correction pulmonic } \\
\text { stenosis; hypothermia } \\
27^{\circ} \mathrm{C} \text {. }\end{array}$ & 54 & 7 & $\begin{array}{l}\text { Died } \\
\text { (4th day) }\end{array}$ & $\begin{array}{l}\text { Pulmonary } \\
\text { regurgitation }\end{array}$ \\
\hline W.G. & $\begin{array}{l}48 \\
M\end{array}$ & A.I. & IV & $\begin{array}{l}\text { Aortic valvuloplasty } \\
\text { with "teflon" } \\
\text { leaflet extension; } \\
\text { hypothermia } 27^{\circ} \mathrm{C} \text {. }\end{array}$ & 60 & 180 & $\begin{array}{l}\text { Died } \\
\text { (operation) }\end{array}$ & $\begin{array}{l}\text { Irreversible } \\
\text { ventricular } \\
\text { fibrillation }\end{array}$ \\
\hline J.C. & $\begin{array}{l}35 \\
\mathbf{M}\end{array}$ & M.I. & III & $\begin{array}{l}\text { Mitral valvuloplasty; } \\
\text { hypothermia } 32^{\circ} \mathrm{C} \text {. }\end{array}$ & 18 & 29 & Survived & \\
\hline D.M. & 50 & M.I. & IV & $\begin{array}{l}\text { Mitral valvuloplasty; } \\
\text { hypothermia } 31^{\circ} \mathrm{C} \text {. }\end{array}$ & 29 & 16 & Survived & \\
\hline M.R. & $\begin{array}{l}38 \\
F\end{array}$ & Pentalogy & III & $\begin{array}{l}\text { Correction of V.S.D., } \\
\text { A.S.D., and } \\
\text { pulmonic stenosis }\end{array}$ & 25 & 25 & $\begin{array}{l}\text { Died } \\
\quad(4 \text { th day) }\end{array}$ & Heart block-arrest \\
\hline R.W. & $\begin{array}{l}37 \\
\mathbf{M}\end{array}$ & A.I., A.S. & III & $\begin{array}{l}\text { Aortic valvuloplasty } \\
\text { with "teflon" leaflet } \\
\text { extension }\end{array}$ & 37 & 27 & $\begin{array}{l}\text { Died } \\
\text { (day of op.) }\end{array}$ & $\begin{array}{l}\text { Herniation of "tefion" } \\
\text { aortic prosthesis }\end{array}$ \\
\hline J.L. & $\begin{array}{l}39 \\
\mathbf{M}\end{array}$ & A.I. & IV & $\begin{array}{l}\text { Aortic valvuloplasty } \\
\text { with "teflon" leaflet } \\
\text { extension }\end{array}$ & 27 & 10 & Survived & \\
\hline B.R. & $\begin{array}{l}33 \\
F\end{array}$ & $\begin{array}{l}\text { M.S., M.I., } \\
\text { A.I. }\end{array}$ & IV & Mitral valvuloplasty* & 36 & 18 & Died & Congestive failure \\
\hline M.G. & $\begin{array}{l}29 \\
F\end{array}$ & M.I. & III & Mitral valvuloplasty & 30 & 7 & $\begin{array}{l}\text { Died } \\
\text { (14th day) }\end{array}$ & $\begin{array}{l}\text { Pulmonary œdema; } \\
\text { supraventricular } \\
\text { tachycardia; } \\
\text { ventricular } \\
\text { fibrillation }\end{array}$ \\
\hline H.R. & $\begin{array}{l}64 \\
\mathrm{M}\end{array}$ & M.I. & III & Mitral valvuloplasty* & 28 & 32 & $\begin{array}{l}\text { Died } \\
\text { (2nd day) }\end{array}$ & $\begin{array}{l}\text { Acute tracheo- } \\
\text { bronchitis; } \\
\text { congestive heart } \\
\text { failure }\end{array}$ \\
\hline M.F. & $\begin{array}{l}34 \\
\mathrm{~F}\end{array}$ & M.I. & IV & Mitral valvuloplasty* & 29 & 11 & Survived & \\
\hline W.B. & $\begin{array}{l}35 \\
\mathbf{M}\end{array}$ & M.I. & IV & Mitral valvuloplasty* & 35 & 8 & $\begin{array}{l}\text { Died } \\
\quad(62 \mathrm{nd} \text { day })\end{array}$ & Cardiac arrest \\
\hline E.O. & $\begin{array}{l}36 \\
F\end{array}$ & M.I., M.S. & IV & Mitral valvuloplasty & 33 & 31 & $\begin{array}{l}\text { Died } \\
\text { (5th day) }\end{array}$ & $\begin{array}{l}\text { Pulmonary } \\
\text { insufficiency; } \\
\text { congestive failure }\end{array}$ \\
\hline & $\begin{array}{l}52 \\
\mathbf{M}\end{array}$ & $\begin{array}{l}\text { Subaortic } \\
\text { stenosis }\end{array}$ & IV & $\begin{array}{l}\text { Correction of subaortic } \\
\text { stenosis* }\end{array}$ & 19 & 18 & $\begin{array}{l}\text { Died } \\
\text { (3rd day) }\end{array}$ & $\begin{array}{l}\text { Bleeding; ventricular } \\
\text { fibrillation }\end{array}$ \\
\hline J.S. & $\begin{array}{l}34 \\
\mathrm{~F}\end{array}$ & M.I. & IV & Mitral valvuloplasty & 25 & 15 & Survived & \\
\hline B.K. & 35 & A.I. & III & Aortic valvuloplasty* & 30 & 70 & Survived & \\
\hline D.R. & $\begin{array}{l}50 \\
\mathbf{M}\end{array}$ & A.S. & IV & Aortic valvuloplasty* & 54 & 26 & $\begin{array}{l}\text { Died } \\
\text { (4th day) }\end{array}$ & $\begin{array}{l}\text { Embolization to } \\
\text { coronary arteries; } \\
\text { myocardial } \\
\text { infarction; } \\
\text { congestive failure }\end{array}$ \\
\hline P.C. & $\begin{array}{l}46 \\
\mathbf{M}\end{array}$ & A.I. & IV & $\begin{array}{l}\text { Aortic valvuloplasty } \\
\text { with "teflon" leaflet } \\
\text { extension* }\end{array}$ & 49 & 150 & $\begin{array}{l}\text { Died } \\
\text { (operation) }\end{array}$ & $\begin{array}{l}\text { Irreversible ventricu- } \\
\text { lar fibrillation; } \\
\text { old coronary }\end{array}$ \\
\hline C.E. & $\begin{array}{l}48 \\
F\end{array}$ & $\begin{array}{l}\text { M.I., A.S. } \\
\text { A.I. }\end{array}$ & IV & Mitral valvuloplasty & 20 & 15 & Survived & ons \\
\hline B.C. & $\begin{array}{l}46 \\
F\end{array}$ & M.I. & IV & Mitral valvuloplasty & 30 & 51 & Survived & \\
\hline R.D. & F & A.S. & IV & Aortic valvuloplasty & 13 & 15 & Survived & \\
\hline
\end{tabular}

Key to abbreviations:

A.I. = Aortic insufficiency

A.S. $=$ Aortic stenosis

M.I. = Mitral insufficiency

M.S. = Mitral stenosis
V.S.D. = Interventricular septal defect

A.S.D. = Interatrial septal defect

* = Attempted acetylcholine arrest

Group III: incapacitated by progressive symptoms.

Group IV: chronic congestive failure, complete invalids. 
through the right atrium by making an incision in the interatrial septum. The site of the incision was well above the location of the specialized conducting tissues and the coronary sinus. Left atrial decompression was used in all cases during the recovery phase. Following the intracardiac procedure partial or total bypass was continued until the heart could maintain the mean blood pressure level above $60 \mathrm{~mm}$. $\mathrm{Hg}$ without evidence of deterioration.

Acetylcholine was used in an attempt to induce cardiac arrest in 9 of the 21 patients, but in only 6 wasit successful, and in all but one of these its effect was transient. This technique was abandoned as a method of inducing standstill because of its ineffectiveness.

The electrocardiogram was monitored continuously at varying speeds, generally $25 \mathrm{~mm}$. $/ \mathrm{sec}$. on a directwriting Grass* multichannel recorder before, during, and after operation. Lead II was used throughout. By necessity there was some variability in the frequency and thoroughness with which this was done. In some patients the earliest changes could not be studied either because of the poor technical quality of the tracings, or because of the administration of acetylcholine which induced standstill of the heart lasting from 12 to 30 seconds, or because of disturbances in rhythm induced directly by surgical manipulation of the heart.

Blood gas studies before institution of the bypass usually indicated that hyperventilatory alkalosis had been produced. During and after cardiopulmonary bypass an attempt was made to maintain the mean blood pressure close to the pre-anæsthetic level by the infusion of blood or vasopressors or both as indicated by changes in the circulation.

\section{RESULTS}

Immediate Effects. In 11 patients extensive observation of electrocardiographic events occurring in the first minute or two of aortic clamping was possible. These consisted predominantly of changes in the ventricular complex. In 6 patients the QRS complex showed a pronounced decrease in voltage; in two of these this was associated with a shift in the electrical axis of the heart. Two of the 11 patients demonstrated a slight elevation of the RS-T segment. In 6 patients the T wave showed a progressive change from inversion and the hammock-shaped depression of the RS-T segment characteristic of digitalis effect, to an upright $T$ wave. In two of the latter, the $T$ wave even became tall and peaked (Fig. 1B). In only 3 instances was a change in rhythm detected in this early period of aortic occlusion: this consisted of the development of an idio-ventricular rhythm from a normal sinus rhythm in one case, of atrial fibrillation in a second, and of second degree atrio-ventricular block in the third.

Later Effects. After 5 to 10 minutes of aortic occlusion, changes in rhythm, in intraventricular and atrio-ventricular conduction, as well as additional changes in the ventricular complex, were observed in all 21 patients. Intraventricular block, manifested as an increase in the duration of the QRS complex, developed in all 21 patients. In 5 of these an elevation of the RS-T segment became apparent (Fig. 2C, D, 3C, D, and 4B, C, D). Two others showed a similar elevation of the RS-T segment before developing intraventricular block. When observed in dynamic sequence this RS-T segment elevation occurred early in the development of, and late in the recession from, the intraventricular conduction disturbance. When conduction defects were most pronounced these shifts were least evident, being presumably enveloped in the resulting total distortion of the ventricular complex which resembled an intracellular electrogram (Fig. 2D).

Nine of the patients showing progressive changes in the QRS complex demonstrated "primary" abnormalities in the $T$ wave as well. In 6 of these the $T$ wave became transiently very large and upright resembling the $T$ waves commonly associated with potassium intoxication or subendocardial ischæmia; in the other 3 the $\mathrm{T}$ wave became symmetrically inverted resembling the so-called coronary $\mathrm{T}$ wave.

Fifteen of the 21 patients showed varying degrees of slowing of the ventricular rate, whether the ventricles were activated from the atria, from the atrio-ventricular node, or from an idio-ventricular focus. One patient developed sinus tachycardia. The remaining 5 manifested ventricular fibrillation before changes in the ventricular rate could be detected. One of the most striking

* Grass Instrument Company, Quincy, Mass. 


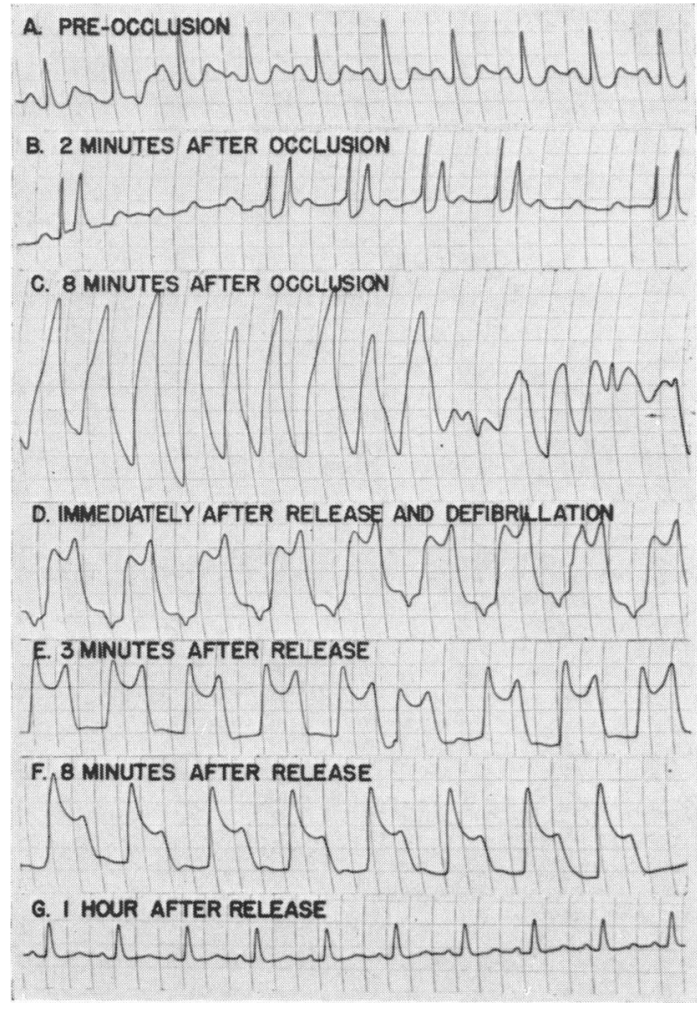

Fig. 1.

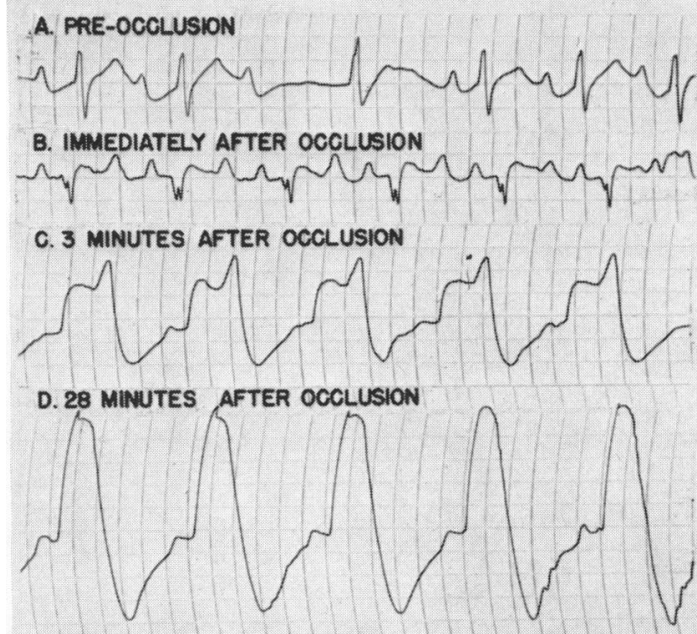

E. I MINUTE AFTER RELEASE

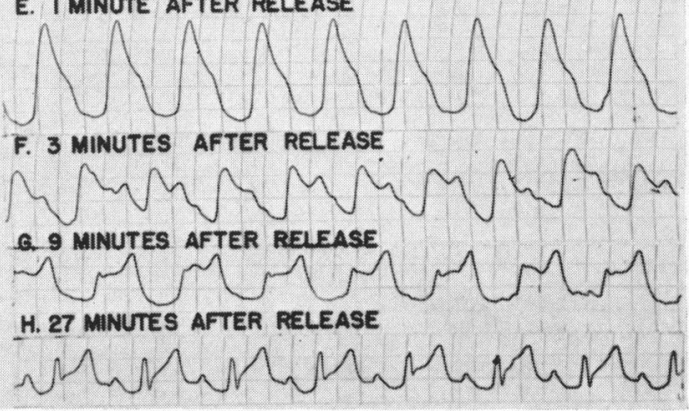

FIG. 2.

FIG. 1.-B.K., 35-year-old man. Open-heart surgery for correction of aortic regurgitation with attempted acetylcholine arrest. Hypothermia not used. Digitalized. (A) Pre-occlusion tracing showing normal sinus mechanism and digitalis effect. (B) Two minutes after continuous aortic occlusion. Acetylcholine effect still manifest. Paper speed now $10 \mathrm{~mm}$./sec. Atrial rate 90; high grade atrio-ventricular block. T waves tall and peaked; RS-T segments deformed, but QRS complexes unaltered. (C) After eight minutes of maintained occlusion. The earlier part of the strip shows ventricular tachycardia or flutter, superseded in the latter part by ventricular fibrillation. (D) Immediately after release of aortic clamp and successful defibrillation. There are deformed monophasic action potentials with a terminal upward spike probably the residual of the tall upright $T$ waves seen in strip B. Rhythm is probably nodal with retrograde atrial activation. (E) Three minutes after release showing probable reversion to normal sinus rhythm. RS-T segment shows less elevation; T wave now smaller than R wave. (F) Five minutes later showing further return of the RS-T toward isoelectric line. (G) One hour after release showing return essentially to pre-occlusion appearance. In this and in the succeeding figures standard lead II was used throughout.

Except where otherwise stated the paper speed was $25 \mathrm{~mm}$. per second.

FIG. 2.-R.W., 37-year-old man. Open-heart surgery for correction of aortic stenosis and regurgitation. Hypothermia or acetylcholine not employed. Digitalized. (A) Pre-occlusion tracing showing variations between first and second degree (partial) atrio-ventricular block and a single escape beat. Slight sinus arrhythmia. (B) Tracing recorded immediately after aortic occlusion showing first degree block and an unexplained change in the form of the QRS complex attributable to change in the position of the heart or to early "ischæmia.". As yet, no intraventricular block. (C) Three minutes after maintained occlusion showing the development of intraventricular block, elevated RS-T segments, and upright T waves taller than the QRS complexes. (D) Twentyeight minutes after occlusion showing fusion of all elements of the ventricular complex, pronounced increase in the height of the R waves, pronounced elevation of the RS-T segment, and apparently late inversion of the T waves. (E) One minute after unclamping aorta showing diminution in height of QRS complex, emergence of intraventricular block, and less pronounced elevation of the RS-T segment, no late inversion of the T waves. (F) Three minutes after release showing increased prominence of $T$ wave with further diminution of $R$ wave. (G) Nine minutes after release showing further decrease in R, increase in T. Atrial activity and therefore atrioventricular conduction time not clearly shown in strips $C$ to $G$. (H) Twenty-seven minutes after release showing re-emergence of clear atrial activity and first degree atrio-ventricular block. QRS has reattained substantially the pre-occlusion appearance, but T waves are a little more prominent and RS-T segments slightly elevated. 
electrocardiographic features was the demonstration in 20 of the 21 patients of some degree of atrio-ventricular block at some time during the period of monitoring. If this was not demonstrable during occlusion because of the early inception of ventricular tachycardia or fibrillation, it was seen during the phase of recovery from the tachycardia. The atrio-ventricular block was complete (Fig. 3F and 4E) in all but two cases. It consisted of first degree (prolonged $\mathrm{P}-\mathrm{R}$ interval) block in one patient and second degree (partial) block in the other. In the two patients with ventricular septal defects the block may well have been the effect of the operation itself, for it persisted long after the termination of the procedure.

Of the 21 patients, 11 developed ventricular fibrillation. In 9 this occurred during the period of occlusion, and in 2 just after release. In 4 of the 9 developing this disturbance while the aorta was occluded, the ventricular fibrillation was preceded by ventricular tachycardia (Fig. 1C) generally of rather brief duration. Four reverted spontaneously: in the remaining 7 an attempt was made to abolish the fibrillation by means of electric countershock therapy. This was successful in 5 patients, but in the remaining 2 effective resuscitation was impossible. One of these alternated between ventricular and nodal tachycardia. The other went into ventricular tachycardia only to redevelop ventricular fibrillation.

Of the 11 patients who developed ventricular fibrillation, 6 had shown atrial fibrillation and 5 normal sinus rhythm before operation. All of those who had atrial fibrillation originally continued to show atrial fibrillation after counter-shock. Of the 5 patients who originally showed a normal sinus mechanism, 3 reverted to the original regular sinus rhythm, one manifested atrial fibrillation after counter-shock, and the remaining patient, who had advanced coronary artery disease, died on the operating table.

Effects Following Release of the Clamp. Soon after release of the aortic clamp all but the two who were not successfully resuscitated, and two more whose tracings were not satisfactory technically, showed some degree of intraventricular block. In 13 of the remaining patients the QRS complexes were very tall as well as wide. Thirteen showed elevation of the RS-T segment which was almost (Fig. 2E and 4D) or completely engulfed in the widened QRS complex. There was considerable overlap between the latter two groups, 11 showing both tall R waves and elevated RS-T segments (Fig. 1E, 4D, E). Those who had shown these changes during the period of aortic occlusion showed them again during the period of recovery (Fig. 2, 3, and 4). In 11, the $T$ waves became transiently upright (Fig. 1D, E, and F, and 4B-F): 6 of these had shown this change during occlusion. It seems likely that, had not ventricular tachycardia or fibrillation interrupted the orderly sequence of these changes, they would regularly have been observed during occlusion. Varying degrees of atrio-ventricular block were seen during recovery in all but one case. In three this was very transient, normal conduction returning within a minute or so of the release of the aortic clamp. It may be stated as a generalization, then, that there was the same orderly sequence in the cardiographic phenomena of recovery as was observed in their development.

In the majority of these patients, the electrocardiogram had returned to its pre-occlusion appearance within an hour after operation. In 15, the QRS complexes and the cardiac mechanism reattained their original form. Of the remaining 6, one developed atrial fibrillation, two persistent atrio-ventricular block, and two nodal or ventricular tachycardia. One showed the slight change in the ventricular complex from an Rs to an $\mathrm{rS}$ configuration. It must be emphasized that these results refer only to cardiographic phenomena and furnished no clue to the ultimate prognosis in an individual patient. Thus one of the patients whose electrocardiogram returned promptly to its pre-occlusion appearance died on the fourth day after operation. It has been shown experimentally (Coraboeuf et al., 1958) that mechanical and electrical events do not necessarily go hand-in-hand. This was illustrated in the recording of regular and co-ordinated electrical activity during the surgical procedure when there were no detectable contractions. Furthermore, in some patients, after restoration of circulation to the heart and despite immediate electrocardiographic improvement, hypotension developed when pump assistance was discontinued. This fall of pressure and resultant inadequate myocardial perfusion promptly reinduced profound cardiographic 


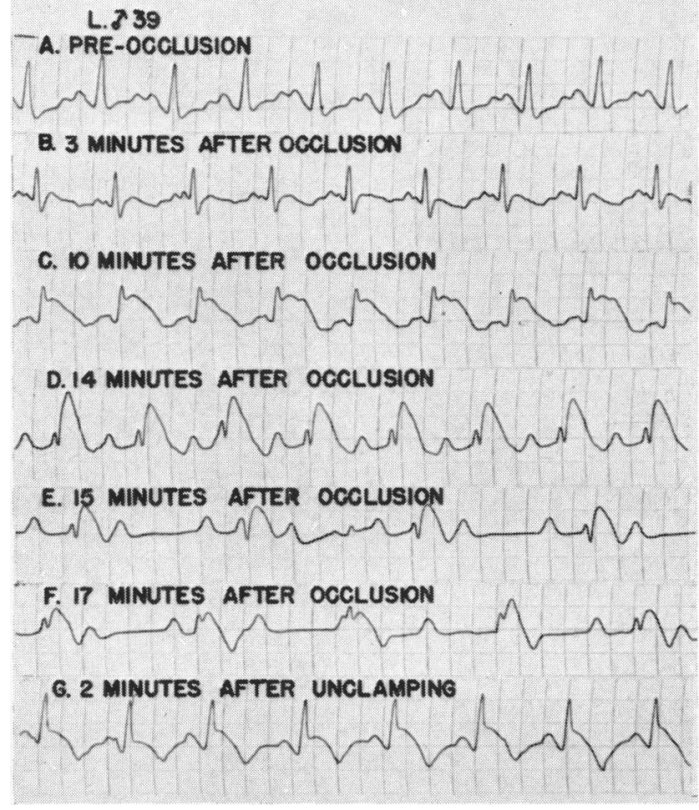

FIG. 3.
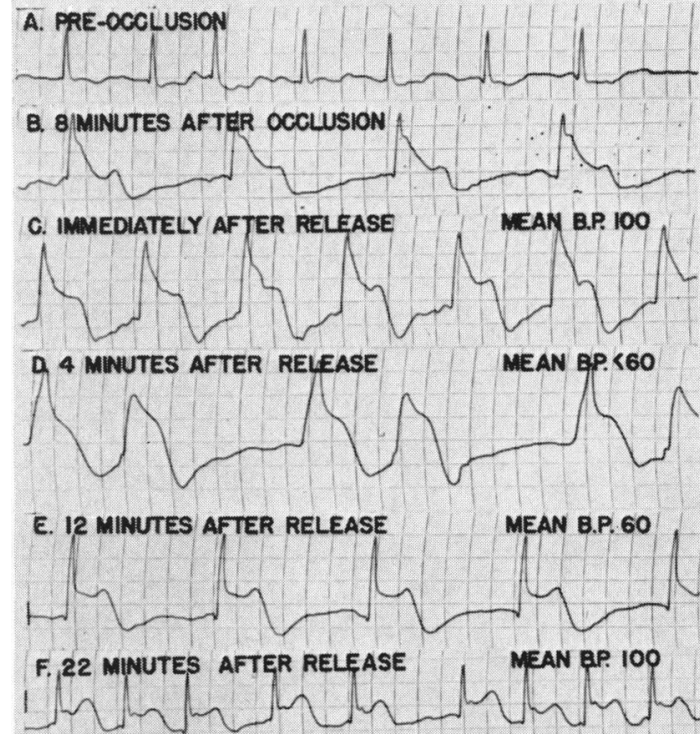

a 2 HOURS AFTER RELEASE

Q.P. $150 / 80$

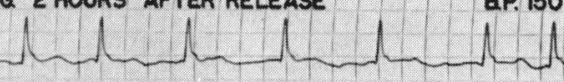

FIG. 4.

FIG. 3.-J. L., 39-year-old man. Open-heart repair for aortic regurgitation. Hypothermia or acetylcholine not used. Digitailized. (A) Pre-occlusion tracing showing normal sinus rhythm, flat $T$ waves and prominent $U$ waves. (B) Tracing three minutes after occlusion showing minor changes consisting of notching of $\mathbf{P}$ waves, slight alteration of QRS complexes, late inversion of the T waves and disappearance of $U$ waves. (C) Ten minutes after occlusion showing pronounced elevation of the RS-T segments. Atrio-ventricular conduction still normal. (D) Fourteen minutes after occlusion showing the development of intraventricular block and first degree atrio-ventricular block. RS-T segment elevation still obvious. (E) One minute later showing second degree atrio-ventricular block. (F) Seventeen minutes after occlusion showing complete atrio-ventricular block. The atrial rate is the same in $\mathrm{E}$ and $\mathrm{F}$. (G) Two minutes after release of clamp showing disappearance of atrioventricular and intraventricular block. Still moderate elevation of the RS-T segments and late inversion of the $T$ waves. Fifteen minutes later RS-T shifts and $T$ wave changes had disappeared and pre-occlusion appearance was reattained.

FIG. 4.-B. C., 46-year-old woman. Open-heart surgery for correction of mitral regurgitation. Hypothermia or acetylcholine not employed. Digitalized. (A) Pre-occlusion tracing showing atrial fibrillation and digitalis effect. (B) After eight minutes of continuous occlusion. Ventricular rate has slowed and ventricular rhythm become regularized, presumably the result of complete atrio-ventricular block. Ventricular complex has become deformed showing a taller $R$ wave. RS-T segment is now elevated and merges into a biphasic $(+-) \mathrm{T}$ wave. (C) Immediately after release of aortic clamp. Rate has increased, rhythm regular in first half of strip, slightly irregular in second half. Prolonged QRS now apparent and RS-T segment elevation more clearly defined. $T$ waves still biphasic. (D) Four minutes after unclamping. Development of bigeminal rhythm after fall in blood pressure to below $60 \mathrm{~mm}$./Hg. (E) Eight minutes later with mean blood pressure restored to 60 ; persistence of complete atrio-ventricular block, disappearance of intraventricular block, and less pronounced RS-T segment elevation. (F) Ten minutes later; return of grossly irregular rhythm and thus of atrio-ventricular conduction. R waves smaller and RS-T shift less pronounced. T wave now upright. (G) Two hours after release of clamp; return to complexes similar to those recorded before occlusion. The change recorded in strip D is slightly atypical in that recovery was complicated by a fall in blood pressure; bigeminal rhythm is not an integral feature of recovery from aortic occlusion.

changes (Fig. 4E, and 5) which were abolished on resumption of the use of the pump oxygenator which restored normal pressure and hence improved perfusion of the heart (Fig. 4G, and 5).

Prolonged circulatory assistance was thus frequently required following cardioplegia when venoarterial bypass was discontinued prematurely. This type of failure was not observed unless arrest had lasted at least 10 minutes. In those patients who survived the operation the periods of such 


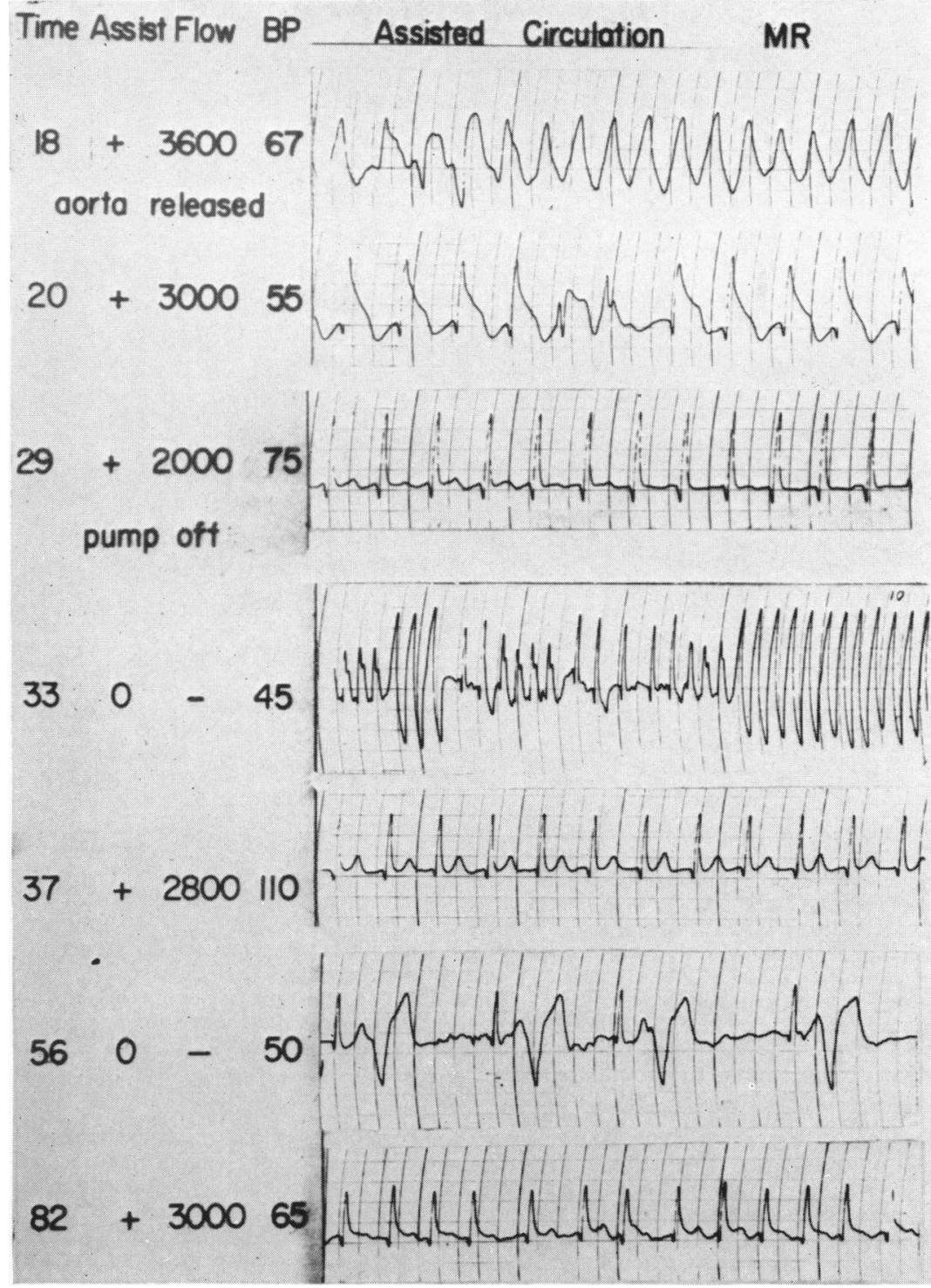

FIG. 5.--M. R., 38-year-old woman. Open-heart surgery for pentalogy of Fallot with attempted acetylcholine arrest. Hypothermia not employed. Digitalized. Time following beginning of aortic occlusion indicated in left-hand column. Second column indicates whether bypass was in operation. Third column shows volume of flow in ml. per minute. Fourth column indicates mean arterial blood pressure $(\mathrm{mm}$. $\mathrm{Hg})$. Tracing at 18 minutes after occlusion shows ventricular fibrillation. Clamp released immediately before 20 -minute strip. This shows disappearance of ventricular fibrillation and its replacement by organized ventricular complexes with a current of injury and two ventricular premature beats. Third strip recorded at 29 minutes shows return to original appearance of electrocardiogram without injury effect, block, or arrhythmia. Fourth strip recorded after interruption of veno-arterial bypass shows development of ventricular tachycardia coincident with a fall in mean arterial pressure from 75 to $45 \mathrm{~mm}$. Hg. Fifth strip recorded 4 minutes after resumption of bypass again shows return to original mechanism coinciding with a rise in mean arterial pressure to $110 \mathrm{~mm}$. Hg. Sixth strip recorded after a second attempt at pump withdrawal showing atrial fibrillation with ventricular premature beats and bigeminal rhythm associated with a fall of arterial pressure to $50 \mathrm{~mm}$. $\mathrm{Hg}$. Final strip following resumption of bypass shows return of electrocardiogram to atrial fibrillation with initial type of ventricular complex and of the arterial pressure to $65 \mathrm{~mm}$. $\mathrm{Hg}$. 
assistance varied from 7 to 70 minutes. As bypass was continued the electrocardiogram showed a progressive improvement in appearance corresponding in a general way to the improvement in myocardial function gauged by direct observation and arterial pressure tracings (Fig. 5). The necessary duration of post-cardiotomy assistance or the need for electrical defibrillation were not correlated with the initial period of arrest.

\section{Discussion}

Before considering the effects produced by clamping the aorta, it is necessary to consider three other factors known to influence the electrocardiogram; namely, hypothermia, acetylcholine, and the mechanical effects of the operative procedure. Hypothermia was used in only 3 patients in the present series and in these the course of events did not differ significantly from that observed in those patients operated on at normal temperature. Acetylcholine was used in 9 patients, but in only 6 was it successful and in 5 of these its effect was transient. It was possible, in fact, to separate an early brief period of arrest due to acetylcholine from later and more persistent changes associated with anoxia. In this respect these observations parallel those made in the experimental animal (Kusunoki et al., 1960). Injury to the major cardiac conduction system is not unusual in operations involving the interventricular septum, and has been reported in operations involving the interatrial septum and the region of the coronary sinus in congenital heart defects (Heim de Balsac, Piot, and Bougaran, 1959). The prompt release of the responsible sutures is frequently followed by the disappearance of an induced block. In only two of the present series was the interventricular or interatrial septum the prime site of surgical intervention. An incision was made through the interatrial septum in most of the mitral operations but the site of the incision was well above the location of the specialized conducting tissues and the coronary sinus and, in these, persistent block was not induced. In the two patients with congenital heart disease the fact that the induced block outlasted the operative period suggested that permanent damage might have been produced in the conduction system. By contrast, the dynamic accession and recession of the electrocardiographic changes generally observed makes it unlikely that such mechanical factors were at play in the remaining cases. By and large, therefore, the cardiographic sequences observed cannot be attributed to hypothermia, to acetylcholine, or to mechanical effects.

The cardiovascular changes produced by clamping the aorta may be due to an interplay of several different factors. The experiments of Tender (1958) suggested that the electrocardiographic changes observed by him were related to reflexes initiated by the altered hæmodynamics. In these observations the occlusion was not total and it is unlikely that ischæmia played a very prominent role in the changes recorded. In the present series, on the other hand, as well as in that of Wagner et al. (1959), aortic occlusion was total and there was no mechanical load on the heart. The extracorporeal circulation maintained the blood flow to the rest of the body as close as possible to the normal. Hence, reflex hæmodynamic factors may be dismissed as being unimportant in inducing the changes observed.

Most deliberate studies on the interruption of coronary blood flow have been concerned with the effects of circumscribed impairment produced by the ligation of main coronary branches (Bayley, LaDue, and York, 1944). These have demonstrated elevation of the RS-T segment at the epicardium overlying induced transmural infarcts and reciprocal depression of the RS-T segment over remote areas. Unless the blood supply to the upper part of the interventricular septum is compromised, there is no tendency to atrio-ventricular block. Very little is known about the effect of throttling coronary blood flow at its source in the proximal ascending aorta. Since blood is supplied thence to the entire heart-atria, conducting tissues, and ventricles alike-one might anticipate the effects of injury at all three levels. But the action potentials of nodal tissue, of the bundle of His, of its branches, and of the Purkinje network, and therefore, "currents of injury" at these levels, are not recorded in the surface electrocardiogram. Therefore, the only cardiographic evidence of damage to the conducting tissues could be atrio-ventricular and intraventricular block. Such 
were the findings in this series. The susceptibility of the junctional tissues to the effects of ischæmia demonstrated experimentally by Bagdonas et al. (1961), is confirmed in man.

The role of digitalis in the production of these disturbances in rhythm and conduction remains to be considered. This drug was used in all patients. Digitalis can induce atrio-ventricular block; but so can anoxia itself. Bagdonas et al. (1961), were impressed with the propensity of ischæmia alone to depress the atrio-ventricular junctional tissues in the non-digitalized experimental animal. Digitalis does not by itself induce intraventricular block; anoxia can and often does. And finally, myocardial ischæmia can induce the type of RS-T segment elevation described here. Apparently when subendocardial in location it can depress the RS-T segment, but in leads to which "left ventricular" potentials are projected, digitalis does not elevate the RS-T segment. Since these changes were restricted to the period of occlusion and that immediately following release, digitalis cannot be considered responsible for them even though it may have modified them.

Bagdonas et al. (1961) found that interruption of the blood supply (ischæmia) resulted in more profound changes than simple hypoxia induced by lowering the oxygen content of the perfusing blood. They postulate that the difference is attributable to a local accumulation, following anoxia, of products that are normally removed when the circulation is intact. The changes observed here bear a striking resemblance to those seen during potassium intoxication. The available clinical and experimental evidence suggests that hypoxia probably acts through the final common path of this type of electrolyte derangement (Coraboeuf et al., 1958; Hoffman and Cranefield, 1960; Kardesch, Hogancamp, and Bing, 1958). The integrity of the cell membrane and the enzyme systems which maintain normal ionic distribution is dependent upon an optimal supply of oxygen to the cell. If oxygen is in short supply the enzymatic systems (potassium or sodium pump) which normally keep the intracellular potassium at a concentration some 30 times that of the extracellular potassium, become ineffective (Kardesch et al., 1958). Potassium then diffuses out of the cell resulting in a decrease in the intracellular and an increase in the extracellular level of this ion, an effect like that of potassium intoxication. In mild form this condition peaks the $\mathrm{T}$ waves, in moderate severity it slows intra-atrial, atrio-ventricular, and intraventricular conduction (Levine, Merrill, and Somerville, 1951). In an experiment of Lewis and Mathison (1910), for example, asphyxia induced by simply turning off the artificial respiration apparatus resulted in a sequence of increasing $\mathrm{T}$ waves, exaggerated $\mathrm{T}$ waves, 2:1 atrio-ventricular block, complete atrio-ventricular block, and atrial standstill. An almost identical sequence has been noted in this series. Deuchar and Muir (1959), reporting their experiences with cardioplegia, note the similarity of the electrocardiographic effects of anoxia and potassium arrest. Unfortunately, we have no direct chemical observations to strengthen this hypothesis. Serial observations were indeed made on the potassium content of the blood perfusing the rest of the body in 6 patients. In 3 this remained unchanged and in 3 others there was a slight fall of the $\mathrm{K}^{+}$level. But this, of course, gives no indication of the extracellular $\mathrm{K}^{+}$content of the non-perfused heart. That the trans-membrane potassium gradient is disturbed in the manner indicated without being reflected in the potassium level measured in the peripheral blood remains therefore a reasonable but unproved possibility.

\section{SUMMARY}

A group of 21 adult patients, all with diseased hearts, all digitalized, most with acquired valvular heart disease but two with congenital heart defects, were subjected to open-heart surgery under bypass. Anoxic cardioplegia, a procedure now obsolete, was induced by clamping the aorta beyond the coronary orifices. Electrocardiograms were recorded before, during, and after this procedure and until the appearance of the pre-operative tracing was reattained.

Three principal electrocardiographic effects were observed. 1. Heart block, consisting of atrioventricular and intraventricular block. 2. RS-T segment shifts or "currents of injury." 3. Arrhythmias.

The severity of these changes or the rapidity of their disappearance following cessation of cardio- 
plegia furnished no clue to the ultimate prognosis for survival after operation though they were associated with and reflected pronounced evidence of functional impairment of the heart. These changes are probably related to global impairment of the blood supply to heart-atria, conducting tissues, and ventricles alike. The changes induced showed a striking resemblance to those seen in potassium intoxication. This suggests that the effects of anoxia are manifested through the final path of a disturbance in electrolyte balance resulting in changes in the transmembrane potentials of myocardial cells.

We are most grateful to Dr. Dwight E. Harken for permission to study these patients and to Dr. Leroy D. Vandam for allowing us to analyse electrocardiograms and anæsthesia charts.

\section{REFERENCES}

Bagdonas, A. A., Stuckey, J. H., Piera, J., Amer, N. S., and Hoffman, B. F. (1961). Effects of ischæmia and hypoxia on the specialized conducting system of the canine heart. Amer. Heart J., 61, 206.

Bayley, R. H., LaDue, J. S., and York, D. J. (1944). Electrocardiographic changes (local ventricular ischæmia and injury) produced in the dog by temporary occlusion of a coronary artery, showing a new stage in the evolution of myocardial infarction. Amer. Heart J., 27, 164.

Coraboeuf, E., Gargouil, Y. M., Laplaud, J., and Desplaces, A. (1958). Action de l'anoxie sur les potentiels électriques des cellules cardiaques de Mammifères actives et inertes. C. R. Acad. Sci. (Paris), 246, 3100.

Deuchar, D. C., and Muir, F. H. (1959). Electrocardiographic changes during cardiac operations performed with a pump-oxygenator. Guy's Hosp. Rep., 108, 218.

Heim de Balsac, R., Piot, C., and Bougaran, J. (1959). L'électrocardiogramme per- et post-operatoire des interventions à cour ouvert sous circulation extracorporelle avec et sans arrêt cardiaque dans 60 cas de cardiopathies congénitales. Acta cardiol. (Brux.), 14, 561.

Hoffman, B. F., and Cranefield, P. F. (1960). Electrophysiology of the Heart, p. 101. McGraw-Hill, New York, London, and Toronto.

Kardesch, M., Hogancamp, C. E., and Bing, R. J. (1958). The effect of complete ischemia on the intracellular electrical activity of the whole mammalian heart. Circulat. Res., 6, 715.

Kusunoki, T., Cheng, H., McGuire, H. H., Jr., and Bosher, L. H. (1960). Myocardial dysfunction after cardioplegia. An experimental study. J. thorac. cardiovasc. Surg., 40, 813.

Levine, H. D., Merrill, J. P., and Somerville, W. (1951). Advanced disturbances of the cardiac mechanism in potassium intoxication in man. Circulation, $3,889$.

Lewis, T., and Mathison, G. C. (1910). Auriculo-ventricular heart-block as a result of asphyxia. Heart, $2,47$.

Tender, M. J. B. (1958). Estudo electrocardiográfico e hemodinãmico em relaçao com o compressão aguda de aorta. Gaz. méd. port., 11, 227.

Wagner, E., Schönbach, G., Thorban, W., and L'Allemand, H. (1959). EKG-Veränderungen nach hypoxämischem Herzstillstand bei Anwendung der Herz-Lungen-Maschine. Langenbecks Arch. klin. Chir., $292,685$. 